\title{
A MODEL FOR PREDICTING AND IMPROVING IRRIGATION WATER MANAGEMENT IN EGYPT - CORN AS A CASE STUDY
}

\author{
N. G. Abd El-Fattah ${ }^{1 \& *}$, H. N. Abd El-Mageed ${ }^{2}$ and M. M. Ibrahim ${ }^{3}$ \\ ${ }^{1}$ Assist. Prof., Ag. Eng. Dept., Fac. of Ag., Mansoura U., (Mansoura, Egypt). \\ ${ }^{2}$ Prof., Ag. Eng. Dept., Fac. of Ag., Mansoura U., (Mansoura, Egypt). \\ ${ }^{3}$ Assoc. Prof., Ag. Eng. Dept., Fac. of Ag., Mansoura U., (Mansoura, Egypt). \\ *E-mail: nadia_gama191@yahoo.com
}

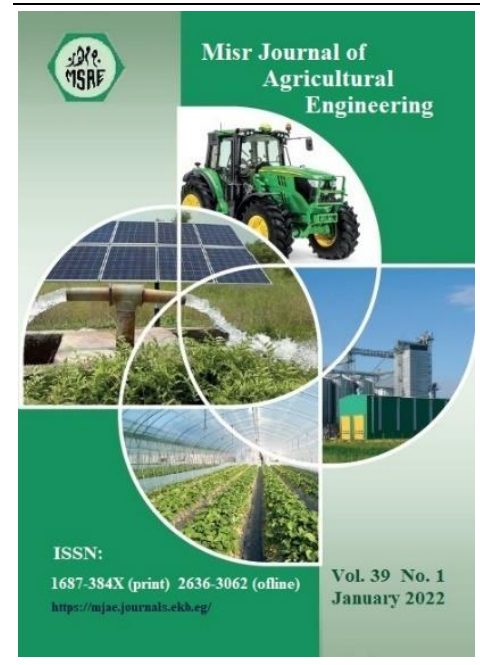

(C) Misr J. Ag. Eng. (MJAE)

\section{Keywords:}

Irrigation water

Management; CAPIM

model; Corn crop; Climate

change; Climate scenarios.

ABSTRACT
Current And Predicted Irrigation Management (CAPIM) model was designed to predict and improve irrigation water management. Its inputs include daily weather data and the outputs are daily evapotranspiration that could be estimated under current conditions using Penman-Monteith equation ( $P$ $M)$, and under climate change using Hargreaves-Samani equation (H-S); and determine the irrigation timing and the amount of water needed for each irrigation event. The CAPIM model was used to develop irrigation schedule for corn crop at different geographic regions in Egypt as (El-Dakahlia; ElFayoum and Assuit) under RCP8.5 scenario and MIROC- ESM climate model during 2018s, 2040s, 2080s. The model was also used to determine the best adaptive strategy for conforming to the predicted climate changes. CAPIM results were verified by comparing them with results from two known programs (CropWat-8 and ETo-Estimation). The results showed that CAPIM was obtained to predict the ETo values under current and predicted climate conditions accurately where the agreement value was 0.99 . Gross irrigation results during the projected periods 2040s and 2080s are higher than 2018s in the three selected sites. El- Fayoum Governorate was the highest in terms of the number of irrigations and the percentage of increasing GIR. As GIR increased by $28 \%$ in 2080s and $29 \%$ in 2040s with 18 hills totaling (2008 and $2077 \mathrm{~mm} / \mathrm{season}$ ), respectively. Moreover, increasing system efficiency by $5 \%$ or $10 \%$ was the best adaptive strategy as it increased the potential yield by about $9 \%$ and $18 \%$ and the WP by $9.4 \%$ and $18.7 \%$.

\section{INTRODUCTION}

$\mathrm{E}$ gypt is water stressed because of aridity, limited natural water resources and increased water demand (Abdel Meguid, 2017). The Nile is the main source for water supply in Egypt. It provides 55.5 billion $\mathrm{m}^{3}$ year $^{-1}$ that accounts for quite $90 \%$ of the water budget, while the remaining $(10 \%)$ comes from renewable and fossil groundwater beside 
rainfall (Abdel-Hafez, 2011). The agriculture sector is the main consumer of water, which consumes $80-85 \%$ of water resources. With only $30 \%$ is effectively utilized by the crop, the remaining is wasted by poor management practices and deep percolation (Mahmoud and ElBably (2017).

Climate has a significant function in the crop yield. More studies showed that over the next hundred years, agriculture yield will likely be severely affected due to unprecedented rates of changes in the climate system (Thornton et al. 2011). Globally, changes in climate are predicted to impact patterns of rainfall and other climatic variables that may lead to significant changes in water supply in many regions and poses an additional threat to water security (Hagemann et al., 2012; Arnell et al., 2011). Climate change would have impacts on water consumption pattern and crop growth, as well as the required irrigation water quantity for well crop growth (Wang et al., 2016).

A theoretical basis for designing the management of agricultural water resources and irrigation water conservation facilities depends on exploring the changes in crop water requirement $(C W R)$ and irrigation requirement $(I R)$ under the circumstance of climate change. Computer models of the climate system are the best tools available for climate variability and change simulation. According to IPCC (2001), confidence on these models reliability for climate projections has improved based on tests of the ability for the present average climate simulation, including the annual cycle of seasonal changes, year-to-year variability, extreme events, such as heat waves and storms, climates from thousands of years ago, and observed climate trends in the recent past.

With the expected low water supplies in Egypt, sustainable irrigation water management water management in agriculture under climate change becomes increasingly important to match water availability and water needs in quantity and quality, in space and time, at reasonable cost and with acceptable environmental impact. Knowledge of crop evapotranspiration allows better scheduling of irrigation, resolving problems in the field of hydrology and meteorology, improving water management, and precisely providing the water needs for crops. Therefore, for sustainable development and water management, the exact water loss estimation through actual evapotranspiration is necessary (Irmak and Irmak, 2008). Various equations are available for estimation evapotranspiration. They include most complex equations such as Penman-Monteith equation (Allen et al., 1989) that requires detailed climatological data. They also include simple equations that require confined data such as Blaney \& Criddle and Hargreaves \& Samani equation (Shahidian et al., 2012).

In Egypt, adaptation in the agrarian sector is highly significant, where water use in agriculture is the greatest among all water users. According to Abouelenein et al. (2009), developing adaptation strategies to reduce climate change risks requires understanding of the climate change potential impacts.

The main objectives of this study are: (1) Developing CAPIM model to predict and improve irrigation water management. (2) using CAPIM model to develop irrigation schedule for corn crop at different geographic regions in Egypt such as (El-Dakahlia; El-Fayoum and Assuit) under RCP8.5 scenario and MIROC- ESM climate model during 2018s, 2040s, 2080s; and (3) determining the best adaptive strategy for conforming to the predicted climate change under the same climate scenario and model. 


\section{METHODOLOGY}

\section{Study areas}

The study area composed of three governorates (El-Dakahlia, El-Fayoum and Assuit) located at different geographic regions in Egypt (Lower, Middle, and Upper Egypt). These governorates have different weather conditions. They are also having the largest cultivated area distributed for corn (BAS, 2014).

\section{Weather data}

Daily meteorological data such as: $T_{\max }, T_{\min }\left({ }^{\circ} \mathrm{C}\right)$, wind speed $\left(u_{2}, \mathrm{~m} / \mathrm{s}\right), R H_{\max }, R H_{\min }(\%)$ and rainfall (mm/day) were obtained from the following website https://www.worldweatheronline.com. The predicted climate data such as predicted $\left(T_{\max }\right.$, $\left.T_{\text {min }},{ }^{\circ} \mathrm{C}\right)$, predicted solar radiation $R_{a}\left(\mathrm{MJ} m^{-2}\right.$ day $\left.^{-1}\right)$, and predicted rainfall $(\mathrm{mm} /$ day) were obtained from http://gismap.ciat.cgiar.org/MarksimGCM for "MIROC-ESM" climate model with the "RCP8.5" scenario through 2040s and 2080s to calculate the reference evapotranspiration under the current condition and under climatic changes.

\section{Soil data}

The soil parameters that were determined for this study included soil texture, soil type, and available water capacity (AWC, $\mathrm{mm} / \mathrm{m}$ ). These parameters vary among the regions on which this study was conducted. The soil texture was clay, sandy clay loam, and sandy loam in ElDakahlia, El-fayoum and Assuit, respectively. The AWC were 192, 183 and $125 \mathrm{~mm} / \mathrm{m}$, respectively.

\section{Crop data}

The crop input data for the CAPIM in the three governorates' is shown in Table 1.

\section{Model description}

The model which is called CAPIM "Current and Predicted Irrigation Management". CAPIM is a computer- based irrigation decision support system that was designed and implemented using Oracle Developer Suite 10g (forms, reports), and Oracle Database10g (PL/SQL Language). This model was used to predict and analyze the effects of short and long-term climate changes on irrigation water management in Egypt for different crops under some of the Representative Concentration Pathways (RCP) using downscaled climate projections from the many General Circulation Models (GCMs) included in the Coupled Model Intercomparison Project Phase 5 (CMIP5). And it also analyzes and evaluates strategies used for adapting to climatic changes so as to mitigate its negative effects on agriculture in Egypt.

CAPIM model is comprised of three basic modules; the first module is the Area Module, the second module is the Irrigation Management Module under Current Climate conditions (IMMCC) and the third module is the Irrigation Management Module under Predicted Climate change (IMMPC) these modules require an important input data items to make calculation and get results as shown in the following flow chart. Also, the model presents the results in form of tables and printed reports. 
Table (1): Initial input data for corn crop in the selected Governorates.

\begin{tabular}{|c|c|c|c|}
\hline Variables & El-Dakahlia & Fayoum & Assuit \\
\hline Crop name & \multicolumn{3}{|c|}{ Corn crop } \\
\hline Planting date & \multicolumn{2}{|c|}{ 15-May } & 1-May \\
\hline Crop height & \multicolumn{3}{|c|}{$2 \mathrm{~m}$} \\
\hline Management Allowable Depletion (MAD) & \multicolumn{3}{|c|}{$55 \%$} \\
\hline Current length of each growth stage (days) & Initial $=20 \quad \mathrm{D}$ & $=35 \quad$ Mid & Late $=30$ \\
\hline Lower threshold temperature $\left(\mathrm{T}_{\text {base }}\right)$ & \multicolumn{3}{|c|}{$8{ }^{\circ} \mathrm{C}$} \\
\hline Upper threshold temperature $\left(\mathrm{T}_{\text {uppe }}\right)$ & \multicolumn{3}{|c|}{$30^{\circ} \mathrm{C}$} \\
\hline Minimum effective rooting depth $\left(\mathrm{Z}_{\mathrm{n}}\right)$ & \multicolumn{3}{|c|}{$0.3 \mathrm{~m}$} \\
\hline Maximum effective rooting depth $\left(Z_{x}\right)$ & \multicolumn{3}{|c|}{$0.9 \mathrm{~m}$} \\
\hline Time to reach $90 \%$ crop emergence $\left(t_{0}\right)$ & \multicolumn{3}{|c|}{10 (days) } \\
\hline Time to reach the maximum $\operatorname{root}\left(\mathrm{t}_{\mathrm{x}}\right)$ & \multicolumn{3}{|c|}{80 (days) } \\
\hline Shape factor of root zone expansion(n) & \multicolumn{3}{|c|}{1.3} \\
\hline Yield response factor $\left(\mathrm{K}_{\mathrm{y}}\right)$ & \multicolumn{3}{|c|}{1.25} \\
\hline Irrigation method & \multicolumn{3}{|c|}{ Surface irrigation } \\
\hline
\end{tabular}

\section{Model validation}

Evaluation is an important step of model verification. The CAPIM model was verified under current and predicted management by comparing its results with the outputs from some readyto-use software programs such as CropWat- 8 Windows version 8.0, introduced by Smith $\boldsymbol{e t}$ al. (2007) in case of current management, and ETo-Estimation program, introduced by Milan and Trajkovic (2010) in case of predicted management, for the estimation of reference evapotranspiration ETo, as assessing changes in ETo is considered a crucial factor in water management on field level. Different statistical indices including $\left(R^{2}\right)$, regression 1:1 and root mean square error (RMSE) according to France and Thornley (1984) were employed to find out how accurate the CAPIM program is to rely on its accounts.

\section{Model application}

After model validation, the model used the weather data for the three selected governorates through 2018s, 2040s and 2080s under "MIROC-ESM" climate model with the "RCP8.5" climate scenario, crop parameter and the soil characteristics for predicting and improving the irrigation water management. These were obtained by estimating the irrigation water applied to the root zone, developing irrigation scheduling and strategies for decreasing the irrigation water demand and increasing the productivity for corn crop by the following equations in this order:

\section{Calculating the effective root depth FAO (2017):}

$$
Z_{r}=Z_{0}+\left(Z_{x}-Z_{0}\right) \sqrt[n]{\frac{t-\frac{t_{0}}{2}}{t_{x}-\frac{t_{0}}{2}}}
$$

Where; $Z_{0}=$ starting depth of the root zone $(\mathrm{m}) ; Z_{x}=$ maximum effective rooting depth $(\mathrm{m}) ; \mathrm{n}$ $=$ shape factor describing root zone expansion; $\mathrm{t}=$ time after planting (days or growing degree days); $t_{0}=$ time to reach $90 \%$ crop emergence (days or growing degree days); $t_{x}=$ time after planting when $Z_{\mathrm{x}}$ is reached (days or growing degree days); and $Z_{n}=$ the minimum effective rooting depth $(\mathrm{m})$. 


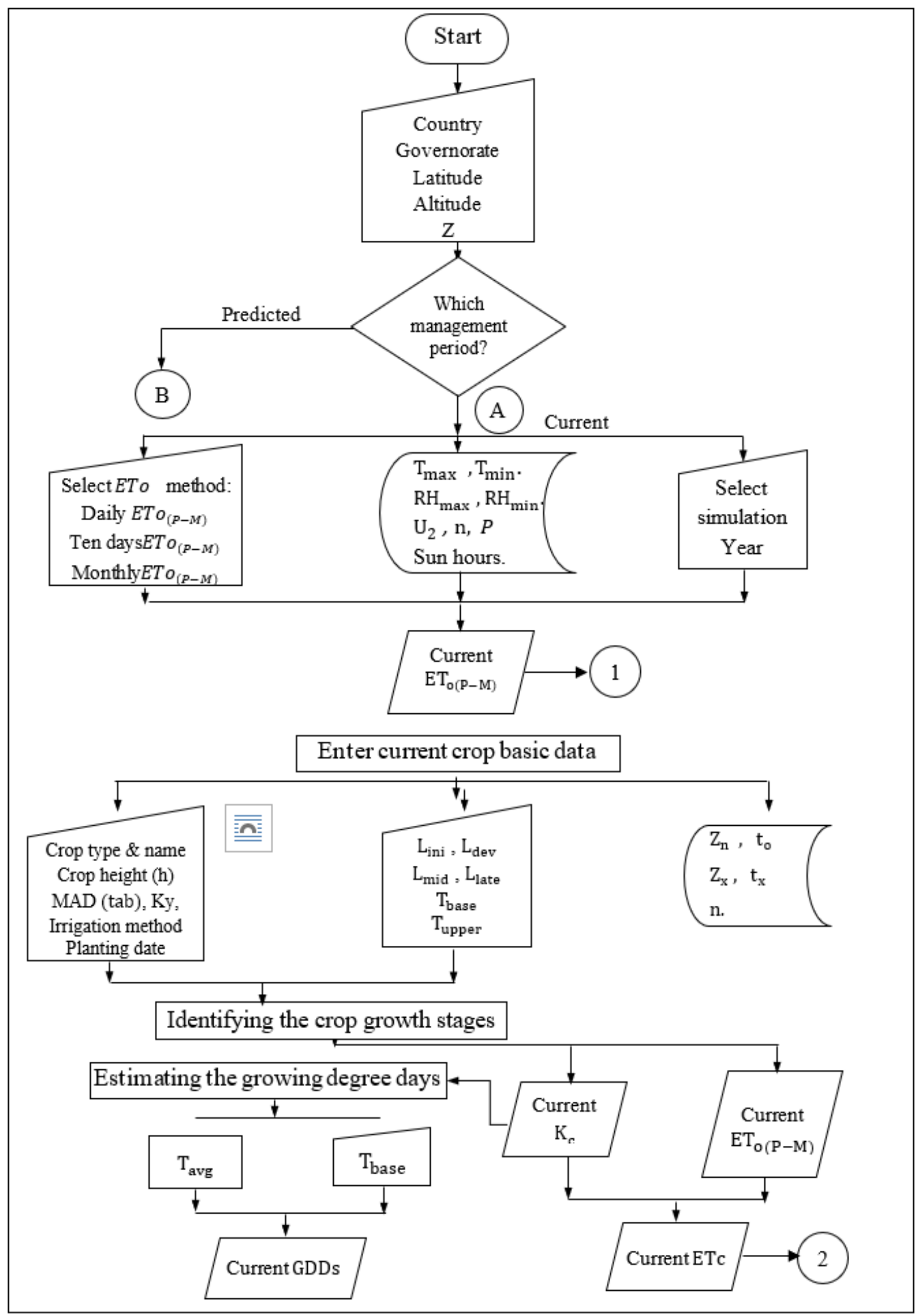

Fig. (1): CAPIM Model schematic diagram. 


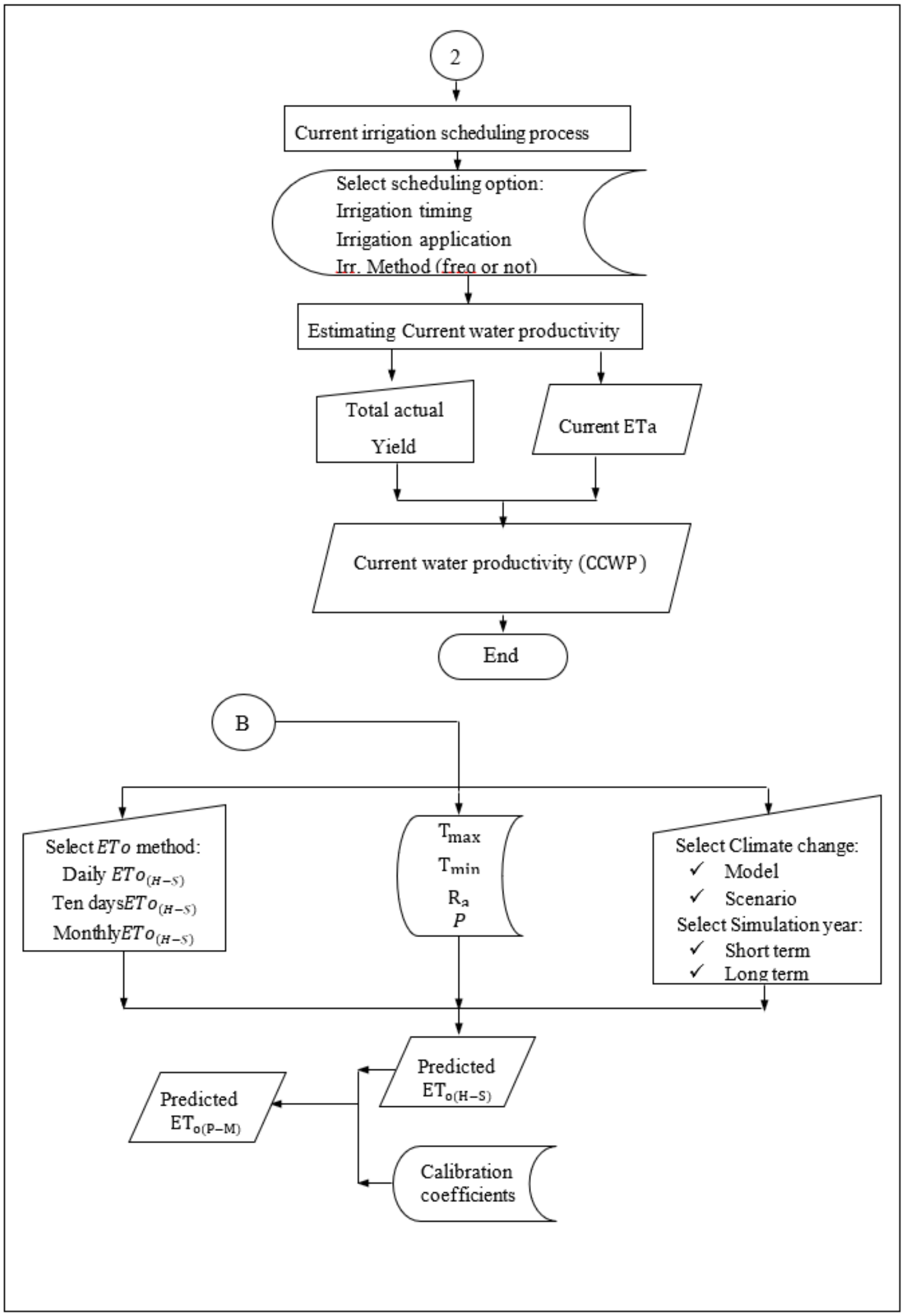

Continued Fig. (1). 


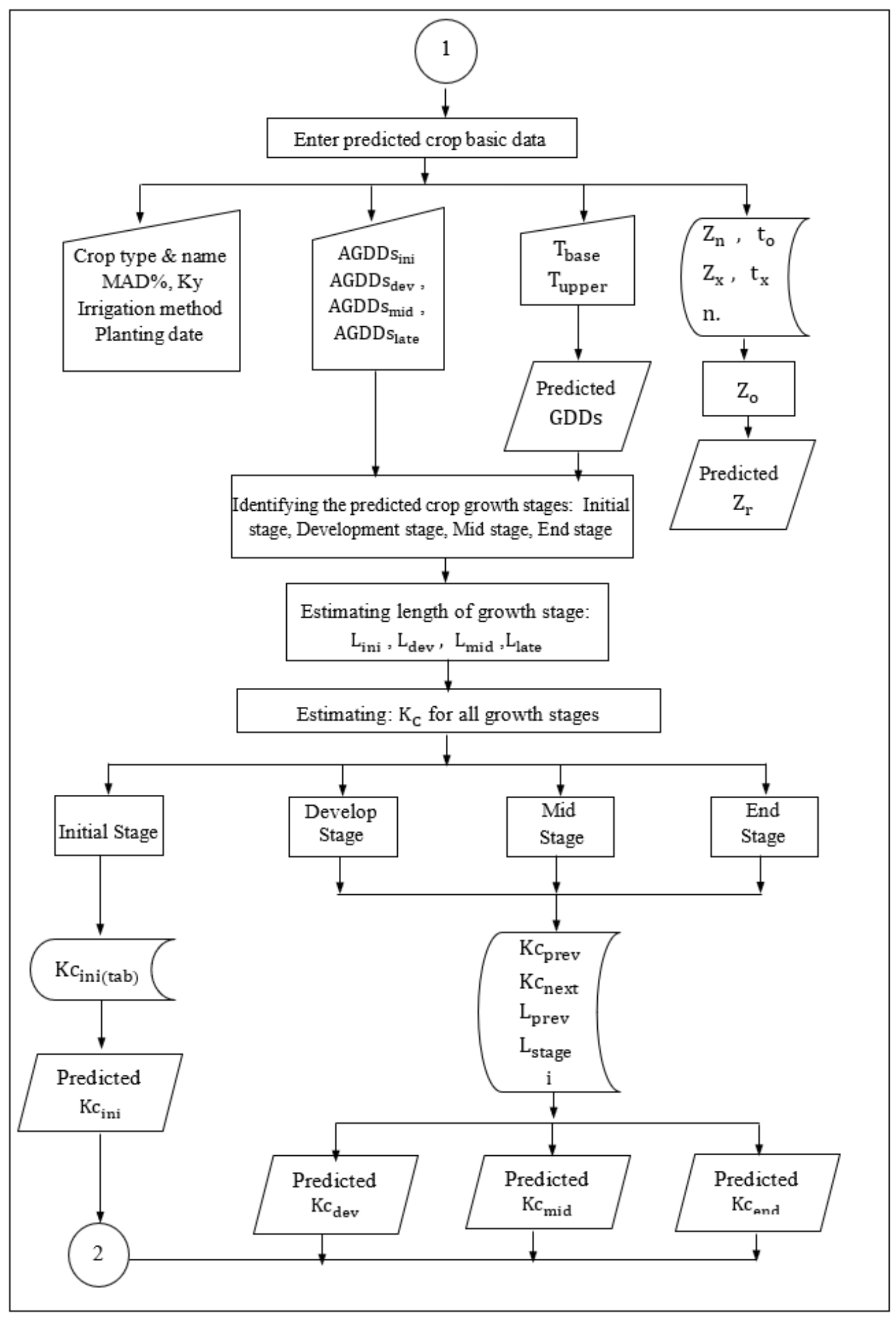

Continued Fig. (1). 


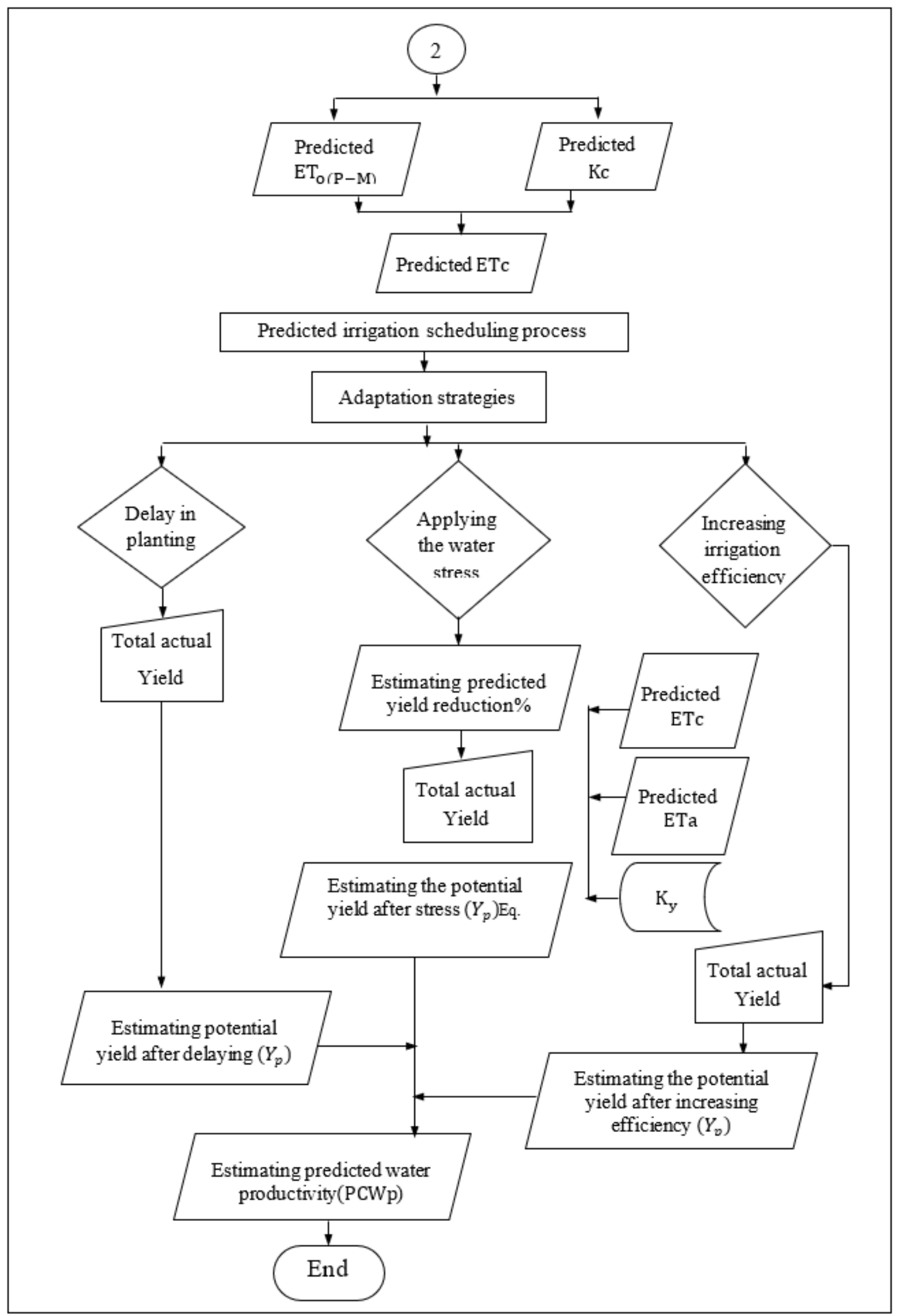

Continued Fig. (1). 
Calculating the total and readily available water as in (FAO 1998):

$$
T A W=A W C \times Z_{r}
$$

Where; AWC $=$ Available water holding capacity $(\mathrm{mm} / \mathrm{m})$ and $Z_{r}=$ Effective root zone depth (m)

$$
R A W=M A D \times T A W
$$

Where; $R A W=$ Readily available water $(\mathrm{mm})$ and $M A D=$ Soil water depletion fraction $(\%)$

\section{Calculating soil water depletion $\left(D_{i}, \mathrm{~mm}\right)$ according to (FAO 1998):}

The world-wide accepted and practiced method, by irrigation researchers and professionals for irrigation scheduling; is the soil-water balance method. This method is computed consistent with crop water use and rainfall by the subsequent equation:

$$
D_{i}=D_{i-1}+\left(E T_{c}-P_{e}\right)_{i}
$$

Where: $D_{i}=$ Soil water depletion $(\mathrm{mm})$ on day I, $D_{i-1}=$ Soil water depletion on day i-1 (mm), for the first day equal zero and $P_{e}=$ Effective rainfall $(\mathrm{mm})$

\section{Calculating gross irrigation requirements $(G I R, \mathrm{~mm}),($ FAO 1998):}

Gross irrigation requirements are the actual amount of water supplied to satisfy crop evapotranspiration and or percolation/seepage observed under field conditions, GIR was calculated by taking into account the leaching requirements and the irrigation system efficiency" Surface irrigation was 55\% in this study ".

$$
\begin{aligned}
& L R=\frac{E C_{w}}{5 E C_{e}-E C_{w}} \ldots \ldots \ldots \ldots \ldots \ldots \ldots \ldots \ldots \ldots \ldots \\
& G I R=\frac{\mathrm{N} I R}{E a / 100^{(1-L R)}} \quad \text { if } L R>0.1
\end{aligned}
$$

Where; $L R=$ the leaching requirement ratio for surface irrigation system (dimensionless), $E C_{w}$ $=$ Electrical conductivity of the irrigation water $(\mathrm{dS} / \mathrm{m}), E C_{e}=$ Electrical conductivity of the soil saturation extract for a given crop appropriate to the tolerable degree of yield reduction $(\mathrm{dS} / \mathrm{m}), G I R=$ Gross irrigation water depth $(\mathrm{mm})$ and $E_{a}=$ Field application efficiency, \% .

\section{Applying strategies for corn crop under climate change condition:}

Three adaptation strategies were considered for corn crop: delaying the planting date, applying water stress and increasing the irrigation system efficiency. The impact of these strategies on the crop productivity, desired irrigation water quantities and on water use efficiency was studied by using the described equations below. Efficient strategy is the one that increases the yield, reduces irrigation water demand and increases water productivity under the tested climatic change model and scenario. The $\mathrm{Wp}$ is a useful indicator for quantifying the impact of irrigation scheduling decisions with regard to water management (Ali and Talukder, 2008).

\section{Delay in the Planting Date}

The planting date is an important determinant of crop production and water use and it was calculated by the following equation: 


$$
Y_{p}=\frac{\mathrm{Y}_{\mathrm{a}} \mathrm{x} \text { The whole lengh of the growth stage after delaying planting }}{\text { The Whole lenght of crop growth stage before delaying planting }}
$$

Where:

$Y_{a}=$ Total actual yield $(\mathrm{kg} / \mathrm{fed})$, and $Y_{p}=$ Potential yield after delaying the planting date (kg/fed).

\section{Applying Irrigation Water Stress}

Water stress coefficient $K_{S}$ is given by the equation (8) that was given by Savva and Frenken (2002). The decrease in relative yield $\left(1-\frac{Y a}{Y m}\right)$ or $Y r$ is consistent with the decrease in relative evapotranspiration $\left(1-\frac{E T a}{E T c}\right)$ given by the formula (10) as described by FAO (1979) and illustrated in order as follows:

$$
\begin{aligned}
& K_{s}=1-\left(\frac{\text { Deficit }}{100}\right) \quad \text { if } D_{i}>R A W \\
& E T a=K_{s} \times E T C \ldots \ldots \ldots \ldots \ldots \ldots \ldots \ldots \ldots \ldots \\
& \left(1-\frac{Y a}{Y m}\right)=K_{y}\left(1-\frac{E T a}{E T C}\right) \ldots \ldots \ldots \ldots
\end{aligned}
$$

If there are yield reduction

$$
\begin{aligned}
& Y_{p 1}=Y_{a} \times Y_{r} \\
& Y_{p}=Y_{a}-Y_{p 1}
\end{aligned}
$$

Where: Deficit $=$ Soil water depletion $(\mathrm{Di}, \mathrm{mm})$ on day i, $\left(1-\frac{Y a}{Y m}\right)$ or $Y r=$ Relative yield reduction $\%,\left(1-\frac{E T a}{E T c}\right)=$ Relative evapotranspiration deficit $\%, Y a=$ actual crop yield $(\mathrm{kg})$, $Y m=$ maximum crop yield $(\mathrm{kg}), K_{y}=$ a yield response factor, dimension less; $E T a=$ Actual crop evapotranspiration (mm/day) and $E T c=$ Crop evapotranspiration for standard conditions ( $\mathrm{mm} /$ day), $Y_{p 1}=$ the decreased amount in actual yield due to the yield reduction $(\mathrm{kg} / \mathrm{fed})$, and $Y_{p}=$ Potential yield after applying water stress $(\mathrm{kg} / \mathrm{fed})$.

\section{Increasing the Irrigation System Efficiency}

The user determines the rate of increase in irrigation system efficiency through the CAPIM model which affects the water demand of irrigation network by the following equation:

$$
Y_{p}=\frac{Y_{a} \times \text { Efficiency of the irrigation system after eff.increment }}{\text { Efficiency of the irrigation system before eff.increment }}
$$

Where: $Y_{p}=$ Potential yield after improving the irrigation system efficiency $(\mathrm{kg} / \mathrm{fed})$, And $Y_{a}=$ Total actual yield $(\mathrm{kg} / \mathrm{fed})$

Finally, calculating the WP in each strategy by the following equation:

Where:

$$
W P=\frac{Y_{p}}{\operatorname{ETa} \times 4.2}
$$

$W P=$ Crop water productivity $\left(\mathrm{kg} / \mathrm{m}^{3}\right)$ and $E T a=$ Actual crop evapotranspiration $(\mathrm{mm} / \mathrm{day})$. 


\section{RESULTS AND DISCUSSION}

\section{CAPIM model verification for current and predicted ETo calculation.}

Dakahlia Governorate was selected as one of the most important governorates present in the study cases to create a verification for the CAPIM model through estimating the reference evapotranspiration where the "ETo" estimation is of great importance for the management of irrigation water, scheduling irrigation and resolving problems in the field of hydrology and meteorology Shahidian et al. (2012) during July 2018s as a current and 2080s as a long term predict using MIROC- ESM climate model with RCP 8.5 climate scenario as example. Figures 2 and 3 show the predicted values of ETo under current and predicted climate. As it can be seen CAPIM model accurately predicted the values of ETo under the current and predicted climate conditions. The analysis of variance results are shown in Tables 2 and 3. Percent difference among the created output of CAPIM model with the CropWat- 8 model in current and ETo-Estimation in prediction of the July 2018s and 2080s was less than 1\%, Root mean squared error (RMSE) was 0.001 and the value of agreement was 0.99 . These results indicated the reliability of CAPIM model in calculating reference evapotranspiration with a high degree of confidence when depending on its results under different irrigation application situations.

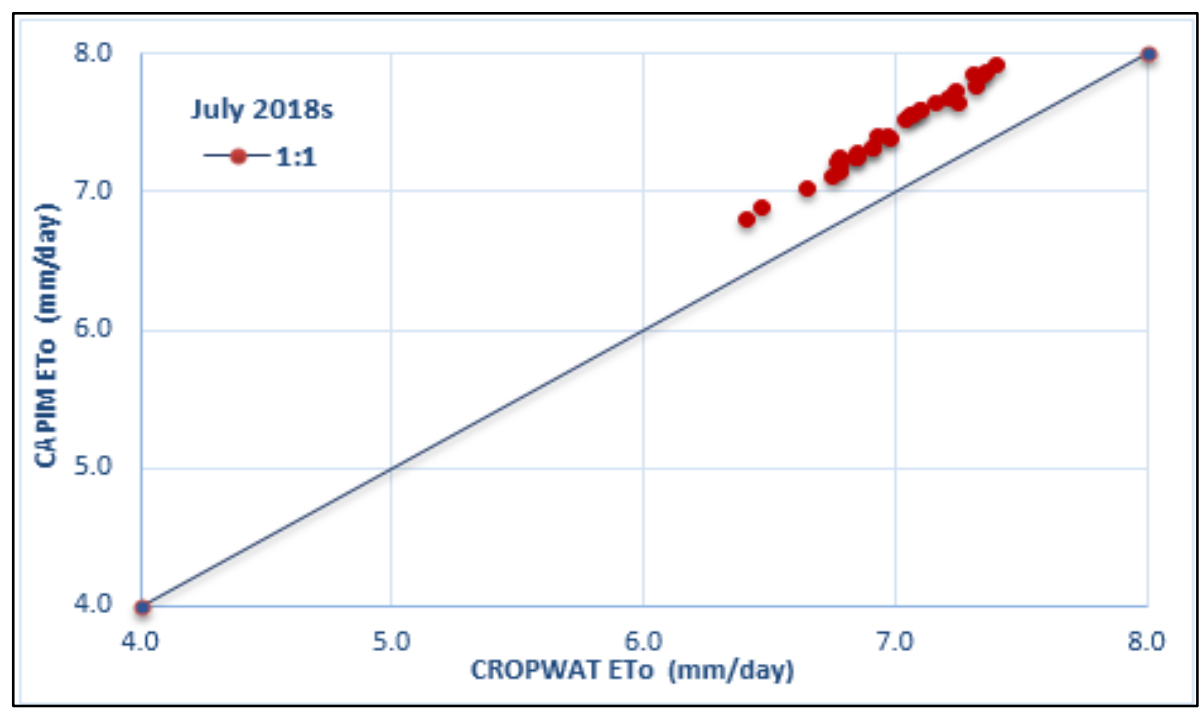

Fig. (2): The correlation of ETo values (mm/day) between CAPIM and CROPWAT models during July 2018s for El-Dakahlia governorate.

Table (2): Analysis of variance for the relationship between "CropWat-8.0" ETo and CAPIM ETo values through July 2018s in El-Dakahlia area.

\begin{tabular}{|c|c|c|c|c|c|}
\hline S.V. & D.F. & S.S. & M.S. & F value & Significance \\
\hline Treat & 1 & 2.654779 & 2.654779 & 2296.085 & $* *$ \\
\hline Residual Error & 29 & 0.03353 & 0.001156 & & \\
\hline Total & 30 & 2.68831 & & & \\
\hline
\end{tabular}

** Highly significant at $1 \%$ level. D.F.= Degrees of Freedom $\quad$ M.S.= Mean squares. S.V.= Sources of Variation $\quad$ S.S.= Sum of Squares 


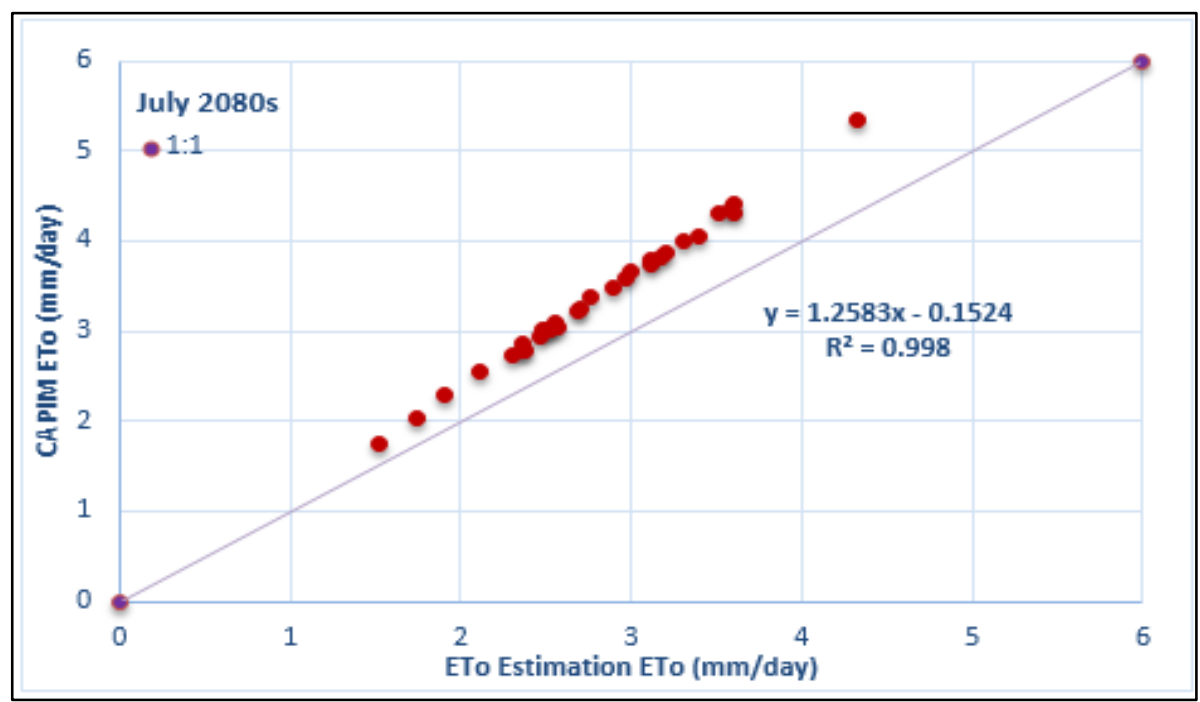

Fig. (3): The correlation of ETo values (mm/day) between CAPIM and ETo Estimation Models during July 2080s for El-Dakahlia governorate.

Table (3): Analysis of variance for the relationship between the "CAPIM Model" ETo and"ETo Estimation Model" ETo through July 2080s in El-Dakahlia governorate for the selected climate change model "MIROC-ESM "and RCP8.5 emission scenario.

\begin{tabular}{|c|c|c|c|c|c|}
\hline S.V. & D.F. & S.S. & M.S. & F value & Significance \\
\hline Treat & 1 & 17.82702 & 17.82702 & 14139.77 & $* *$ \\
\hline Residual Error & 29 & 0.036562 & 0.001261 & & \\
\hline Total & 30 & 17.86359 & & & \\
\hline
\end{tabular}

** Highly significant at $1 \%$ level. D.F.= Degrees of Freedom $\quad$ M.S.= Mean squares.

S.V.= Sources of Variation S.S.= Sum of Squares

Gross irrigation for Corn crop under current and predicted climate

Fig. (4) and Table (4) show the gross irrigation requirements for corn crop along the growth season under 2018s and predicted climate (2040s and 2080s). The total gross irrigation in 2018s was $1808.29 \mathrm{~mm}, 1572.72 \mathrm{~mm}$ and $1275 \mathrm{~mm}$ in Assuit, El-Fayoum, and El-Dakahlia, respectively. Whereas, in 2040s it would be $2076.99 \mathrm{~mm}, 2076.99 \mathrm{~mm}$ and $1618.16 \mathrm{~mm}$; and in 2080s, it would be $2068.64 \mathrm{~mm}, 2008.4 \mathrm{~mm}$ and $1523.9 \mathrm{~mm}$, respectively. Generally, the results illustrated the expected higher amounts of gross irrigation for corn crop in projected periods than 2018s in the three selected sites because of the projected increments in the crop evapotranspiration and crop water requirements.

Table (4): Total gross water requirements $(\mathrm{mm})$ and Percentage Increase (PI \%) for corn crop in the three selected governorate under 2018s, 2040s and 2080s climate.

\begin{tabular}{|l|c|c|c|c|c|}
\hline \multirow{4}{*}{ Governorates } & \multicolumn{4}{|c|}{ Gross irrigation (mm/season) for corn crop } \\
\cline { 2 - 6 } & $\begin{array}{l}\text { Current } \\
\text { climate }\end{array}$ & \multicolumn{4}{|c|}{ Predicted climate } \\
\cline { 2 - 6 } & $\mathbf{2 0 1 8 s}$ & \multicolumn{2}{|c|}{ 2040s } & \multicolumn{2}{c|}{ 2080s } \\
\cline { 2 - 6 } & Total & Total & PI & Total & PI \\
\hline El-Dakahlia & 1275 & 1618 & 27 & 1524 & 20 \\
\hline El-Fayoum & 1573 & 2035.7 & 29 & 2008 & 28 \\
\hline Assuit & 1808 & 2077 & 15 & 2069 & 14 \\
\hline
\end{tabular}




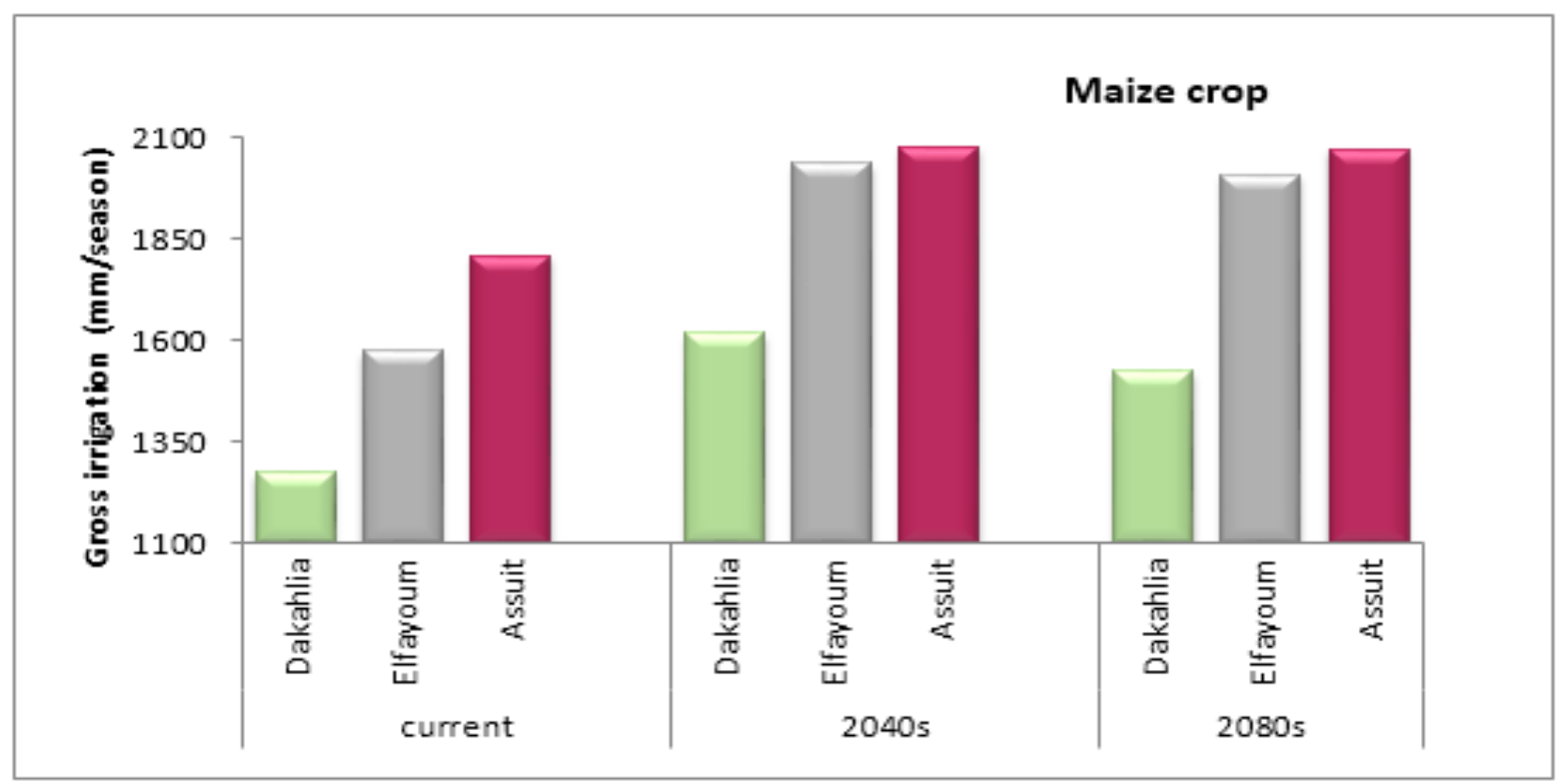

Fig. (4): Seasonal gross irrigation water requirements ( $\mathrm{mm} / \mathrm{season})$ for corn crop at the three selected governorate under the current, 2040s and 2080s.

\section{Irrigation schedule developed by CAPIM model for corn crop under the current and predicted climate conditions}

The CAPIM detailed output for corn real time irrigation scheduling in El-Dakahlia, ElFayoum and Assuit under 2018s and predicted 2040s, 2080s are shown in Figs. (5, 6 and 7). The daily deficit of corn along the whole season are plotted together with the daily RAW and rainfall. In El-Dakahlia, corn scheduling showed 11 peaks totaling $1275 \mathrm{~mm} / \mathrm{season} ; 14$ peaks totaling $1618 \mathrm{~mm} / \mathrm{season}$; and 14 peaks totaling $1524 \mathrm{~mm} / \mathrm{season}$ in 2018s, 2040s and 2080s, respectively. Each of them represented the applied amount of water in each irrigation time. The rainfall values in current and the predicted periods can also be seen. The RAW curve in the three periods showed no difference as it increased gradually till reaching a fixed rate in the late stage, which could be explained by that the $\mathrm{Zr}$ starts to increase from an initial depth to the maximum effective rooting depth.

Corn irrigation scheduling in El-Fayoum governorate under 2018s and predicted climate is shown in Fig. (6). As it can be seen, in 2018s, there were 14 peak totaling $1573 \mathrm{~mm} / \mathrm{season}$. While in future projections there were 18 peaks totaling $2077 \mathrm{~mm} / \mathrm{season}$ and 18 peaks totaling $2008 \mathrm{~mm} / \mathrm{season}$ in 2040s and in 2080s, respectively. Each of these peaks represented the irrigation water amount in each episode.

The results of the developed irrigation scheduling by the CAPIM model revealed that ElFayoum Governorate was one of the highest governorates in terms of the number of irrigations and the percentage of increasing gross irrigation water requirements during the current 2018s and expected management periods 2040s and 2080s. As the GIR increased by $28 \%$ in 2080 s and $29 \%$ in 2040s with 18 peaks totaling 2008 and $2077 \mathrm{~mm} / \mathrm{season}$, respectively.

The corn scheduling in Assuit is shown in Fig. (7). For 2018s, there were 13 peaks totaling $1808 \mathrm{~mm} / \mathrm{season}$, and in 2040s there were 15 peaks totaling $2077 \mathrm{~mm} / \mathrm{season}$. Whereas; in 2080s there were 15 peaks totaling $2069 \mathrm{~mm} / \mathrm{season}$. 

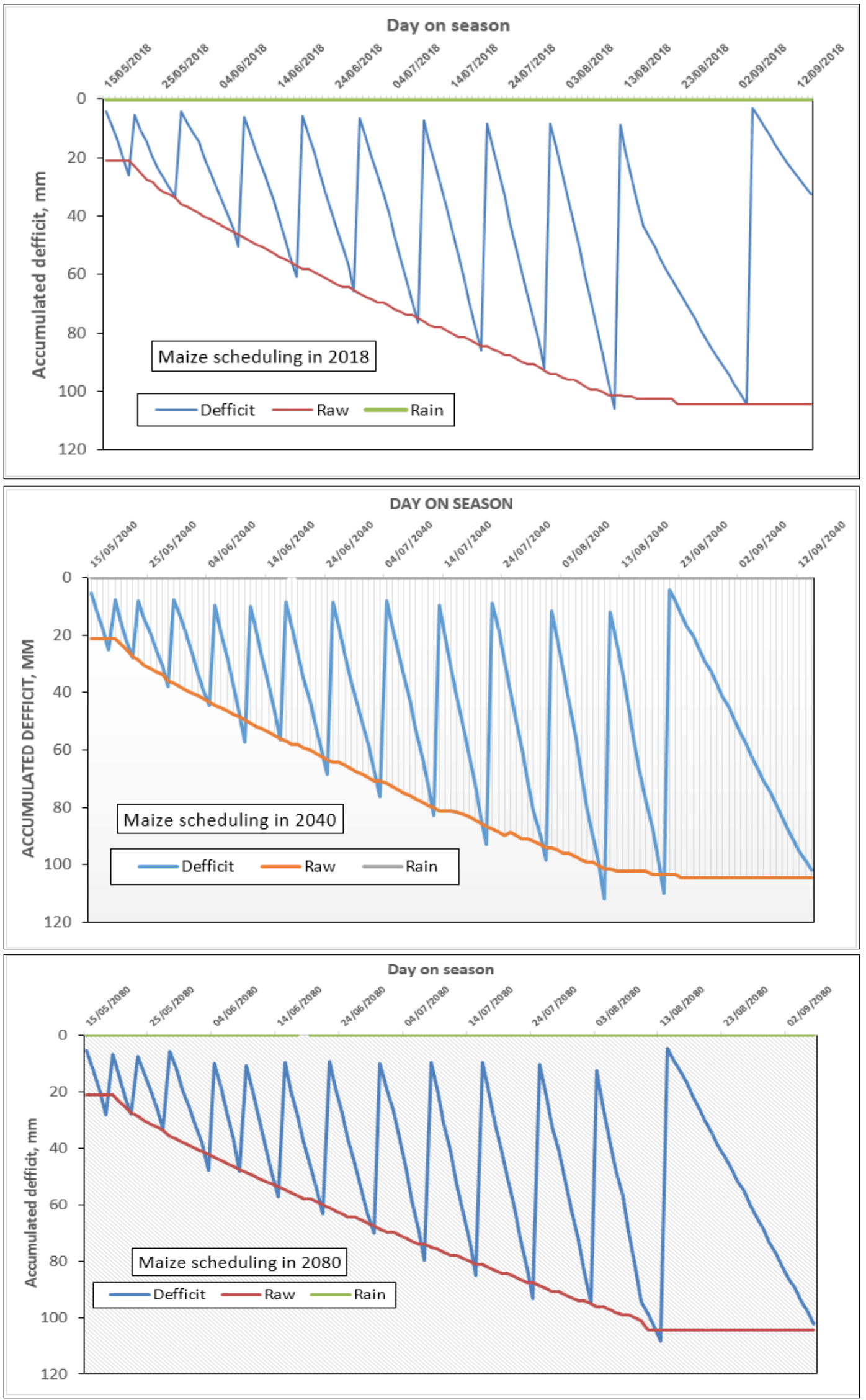

Fig. (5): Simulation the depletion of the irrigation amounts developed by the CAPIM model for corn crop under 2040s, 2080s using RCP8.5 scenario along with $2018 \mathrm{~s}$ in El-Dakahlia governorate. 

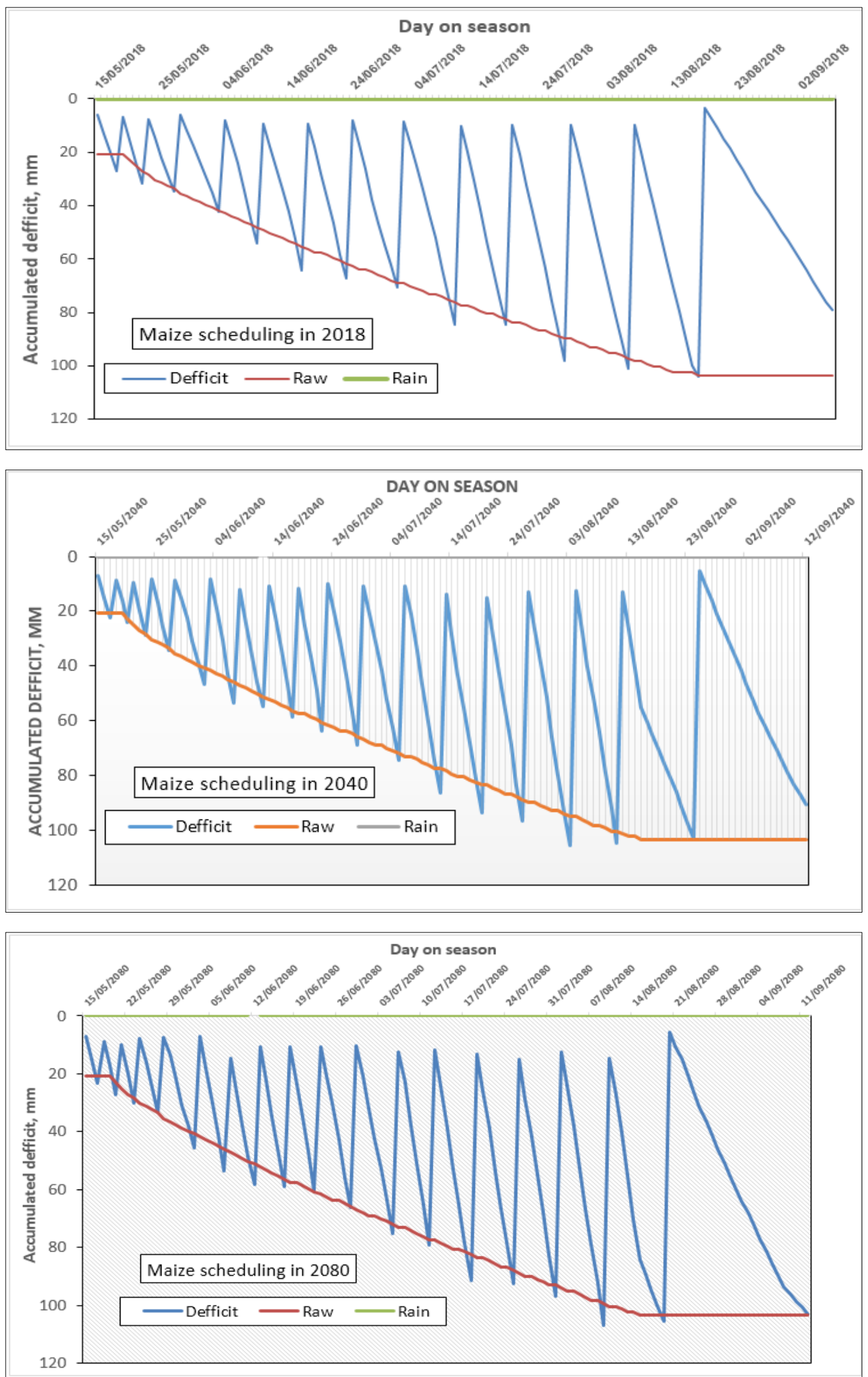

Fig. (6): Simulation the depletion of the irrigation amounts developed by the CAPIM model for corn crop under 2040s, 2080s using RCP8.5 scenario along with 2018 s for El-Fayoum governorate. 

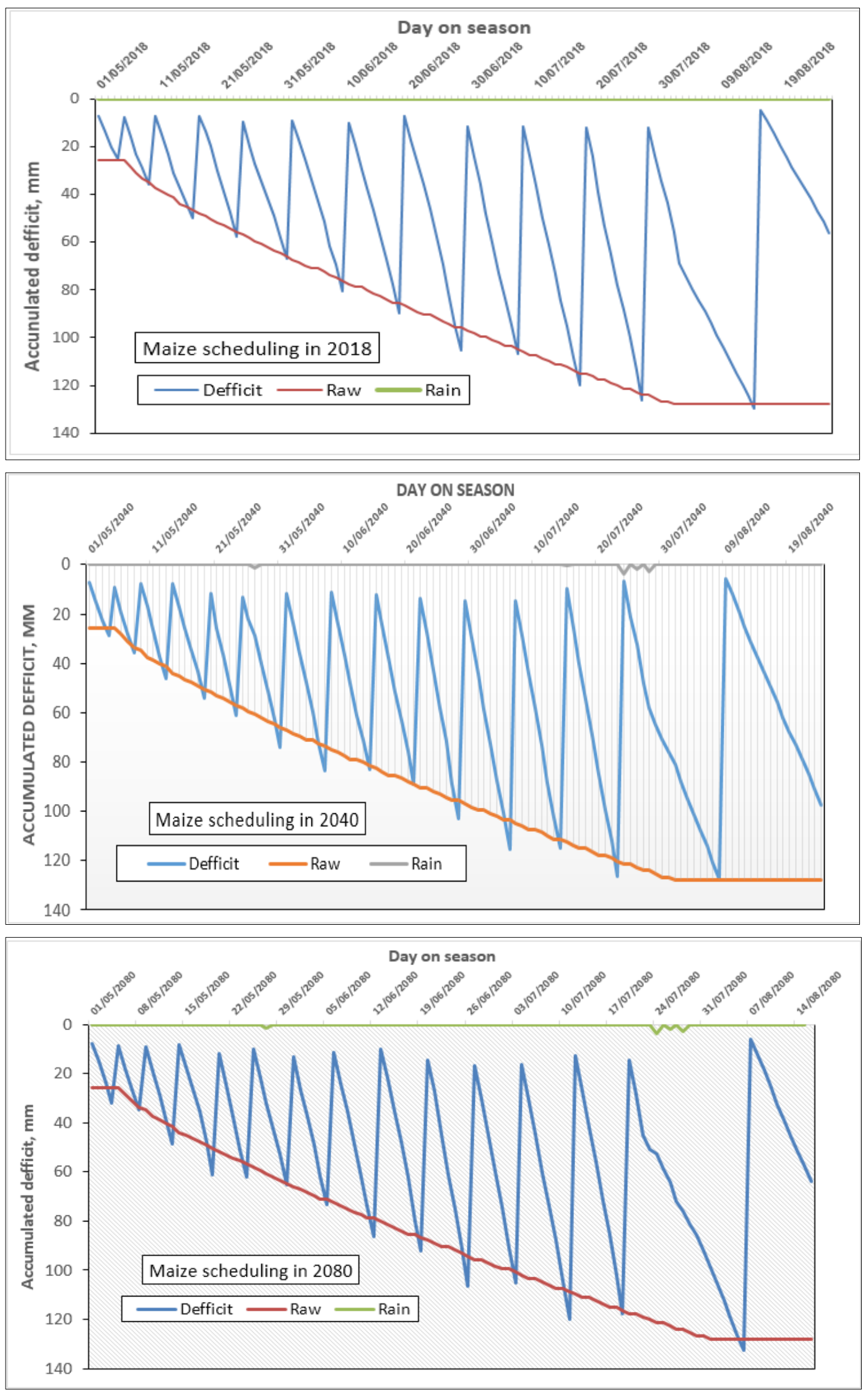

Fig. (7): Simulation the depletion of the irrigation amounts developed by the CAPIM model for corn crop under 2040s, 2080s using RCP8.5 scenario along with 2018s for Assuit governorate. 
Effect of adaptation strategies developed by CAPIM model on the irrigation water amount, and corn crop yield and water productivity

The three strategies for corn crop under predicted climate applied in El-Dakahlia governorate which was selected among the three governorates as one of the largest cultivated districts and main strategic source for corn production in Egypt are shown in Table (5). The outputs of delaying the planting date one week as a first proposed strategy showed that there was a two days predicted decrease in season length of corn when compared to that without strategy and a decrease in the amount of GIR where it reaches $1473 \mathrm{~mm} /$ season and the potential yield by about $1.62 \%$ respectively along the corn season as shown in Fig. (8). whereas, there was an expected increase in WP by about $2.1 \%$. Application of the second strategy; (water stress by $15 \%$ and $30 \%$ ), revealed that there was no change in the length of corn growing season. While, the GIR would be reduced as it reached to 1375.5 and $1132.7 \mathrm{~mm} / \mathrm{season}$ and also the potential yield would be reduced by about $18.8 \%$ and $37.5 \%$ when applying the $15 \%$ and 30 $\%$ water stress strategy respectively as shown in Fig. (9). For the WP under the $15 \%$ and 30 $\%$ water stress was expected to decrease by about $4.2 \%$ and $10.4 \%$, respectively.

Table (5): Irrigation water requirements, potential yield and $C W P$ for corn crop by using MIROC-ESM climate Model with RCP8.5 scenario in El-Dakahlia governorate during 2040 with and without adaptation strategies.

\begin{tabular}{|c|c|c|c|c|c|c|c|}
\hline \multirow{3}{*}{ 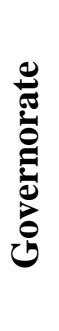 } & \multirow{3}{*}{ Variables } & \multirow{3}{*}{$\begin{array}{c}\text { Without } \\
\text { adaptation }\end{array}$} & \multicolumn{5}{|c|}{ With adaptation } \\
\hline & & & \multirow{2}{*}{$\begin{array}{c}\begin{array}{c}\text { Strategy1 } \\
\text { (With } \\
\text { delaying } \\
\text { planting) }\end{array} \\
7 \text { days }\end{array}$} & \multicolumn{2}{|c|}{$\begin{array}{c}\text { Strategy2 } \\
\text { (With applying water } \\
\text { stress) }\end{array}$} & \multicolumn{2}{|c|}{$\begin{array}{c}\text { Strategy3 } \\
\text { (With increasing } \\
\text { irrigation system } \\
\text { efficiency) }\end{array}$} \\
\hline & & & & $15 \%$ & $30 \%$ & $5 \%$ & $10 \%$ \\
\hline \multirow{11}{*}{ 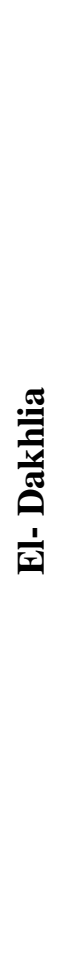 } & Planting Date & $15 / 05 / 2040$ & $22 / 05 / 2040$ & $15 / 05 / 2040$ & $15 / 05 / 2040$ & $15 / 05 / 2040$ & $15 / 05 / 2040$ \\
\hline & Harvest Date & $14 / 09 / 2040$ & $19 / 09 / 2040$ & $14 / 09 / 2040$ & $14 / 09 / 2040$ & $14 / 09 / 2040$ & $14 / 09 / 2040$ \\
\hline & $\begin{array}{l}\text { length of the } \\
\text { crop season } \\
\text { (day) }\end{array}$ & 123 & 121 & 123 & 123 & 123 & 123 \\
\hline & Change rate & & -2 days & \multicolumn{2}{|c|}{ No change } & \multicolumn{2}{|c|}{ No change } \\
\hline & $\begin{array}{l}\operatorname{ETa}(\mathbf{m m} / \\
\text { season) }\end{array}$ & 992.1 & 955.91 & 843.2 & 694.5 & 992.1 & 992.1 \\
\hline & $\begin{array}{l}N I R(\mathrm{~mm} / \\
\text { season) }\end{array}$ & 890 & 810.2 & 756.5 & 623 & 890 & 890 \\
\hline & $\begin{array}{l}\text { GIR }(\mathrm{mm} / \\
\text { season) }\end{array}$ & 1618 & 1473.1 & 1375.5 & 1132.7 & 1483.32 & 1369.22 \\
\hline & $\begin{array}{l}\text { Potential yield } \\
\text { (kg/Fed) }\end{array}$ & 4016 & 3951 & 3263 & 2510 & 4381 & 4746 \\
\hline & Change rate $(\%)$ & & -1.62 & -18.8 & -37.5 & 9.09 & 18.18 \\
\hline & $C W P\left(\mathrm{~kg} / \mathrm{m}^{3}\right)$ & 0.96 & 0.98 & 0.92 & 0.86 & 1.05 & 1.14 \\
\hline & Change rate (\%) & & 2.1 & -4.2 & -10.42 & 9.38 & 18.75 \\
\hline
\end{tabular}


In regards to the third strategy of increasing irrigation system efficiency by $5 \%$ or $10 \%$ it was projected to be better than first and second strategies, as the length of corn growth season would be not changed, while the GIR was expected to decrease as it reached 1483 and 1369 $\mathrm{mm} / \mathrm{season}$ under $5 \%$ and $10 \%$ increasing efficiency strategy respectively. Also, increase in the potential yield by about $9 \%$ and $18 \%$ and the WP by $9.4 \%$ and $18.7 \%$ using the strategy of $5 \%$ and $10 \%$ increasing efficiency, respectively was predicted as illustrated in Fig. (10).

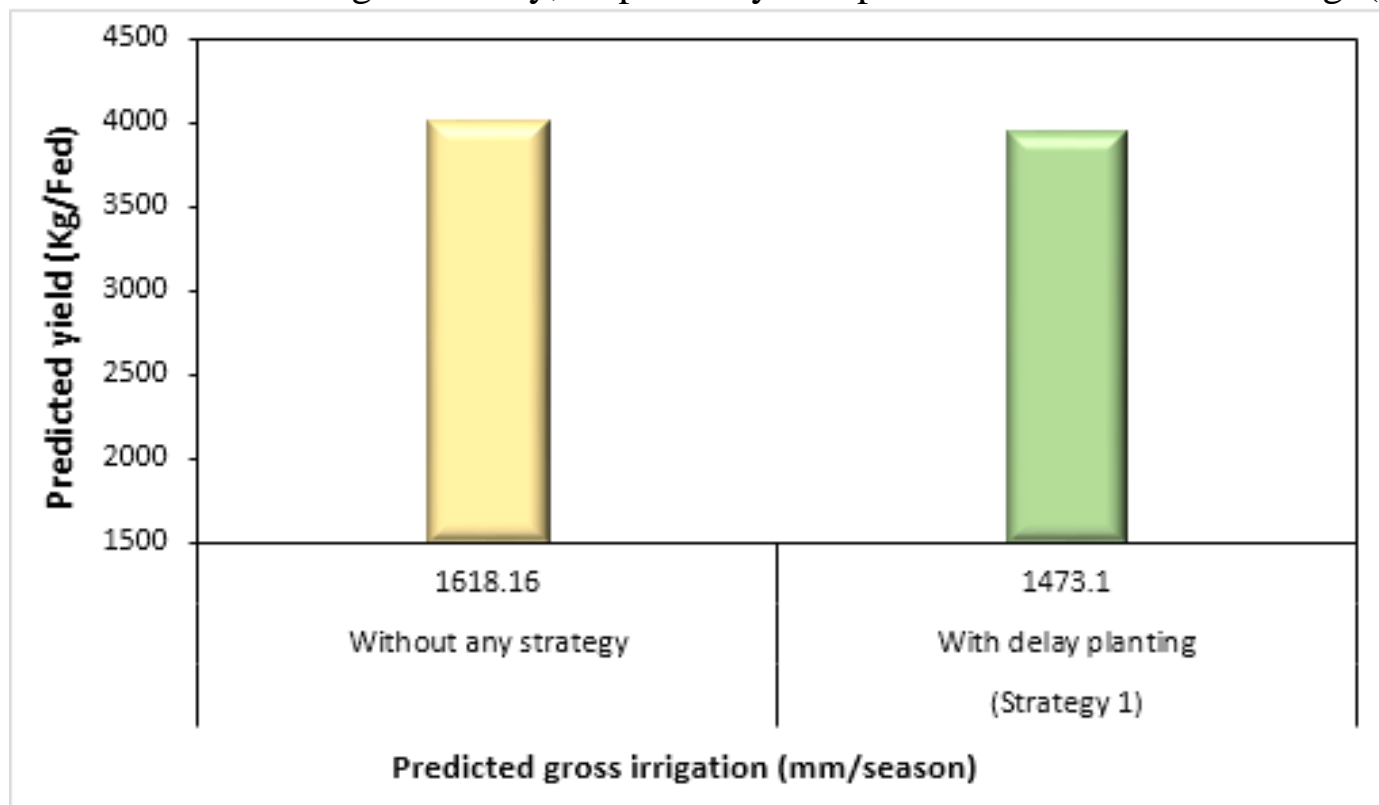

Fig. (8): Relationship between the predicted changes in yield and gross irrigation for corn crop in El-Dakahlia governorate during 2040s under strategy1.

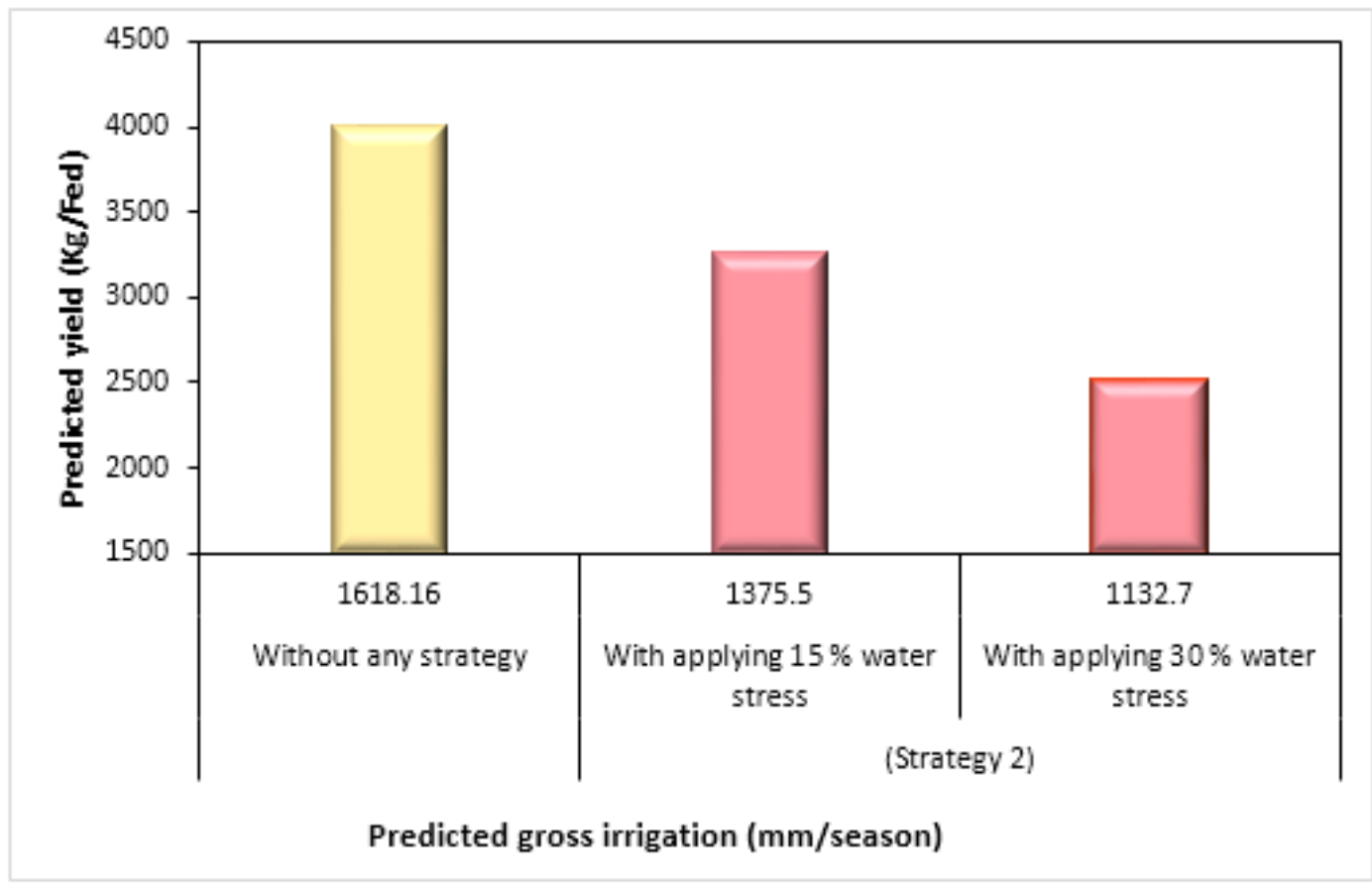

Fig. (9): Relationship between the predicted changes in yield and gross irrigation for corn crop in El-Dakahlia governorate during 2040s under strategy2. 


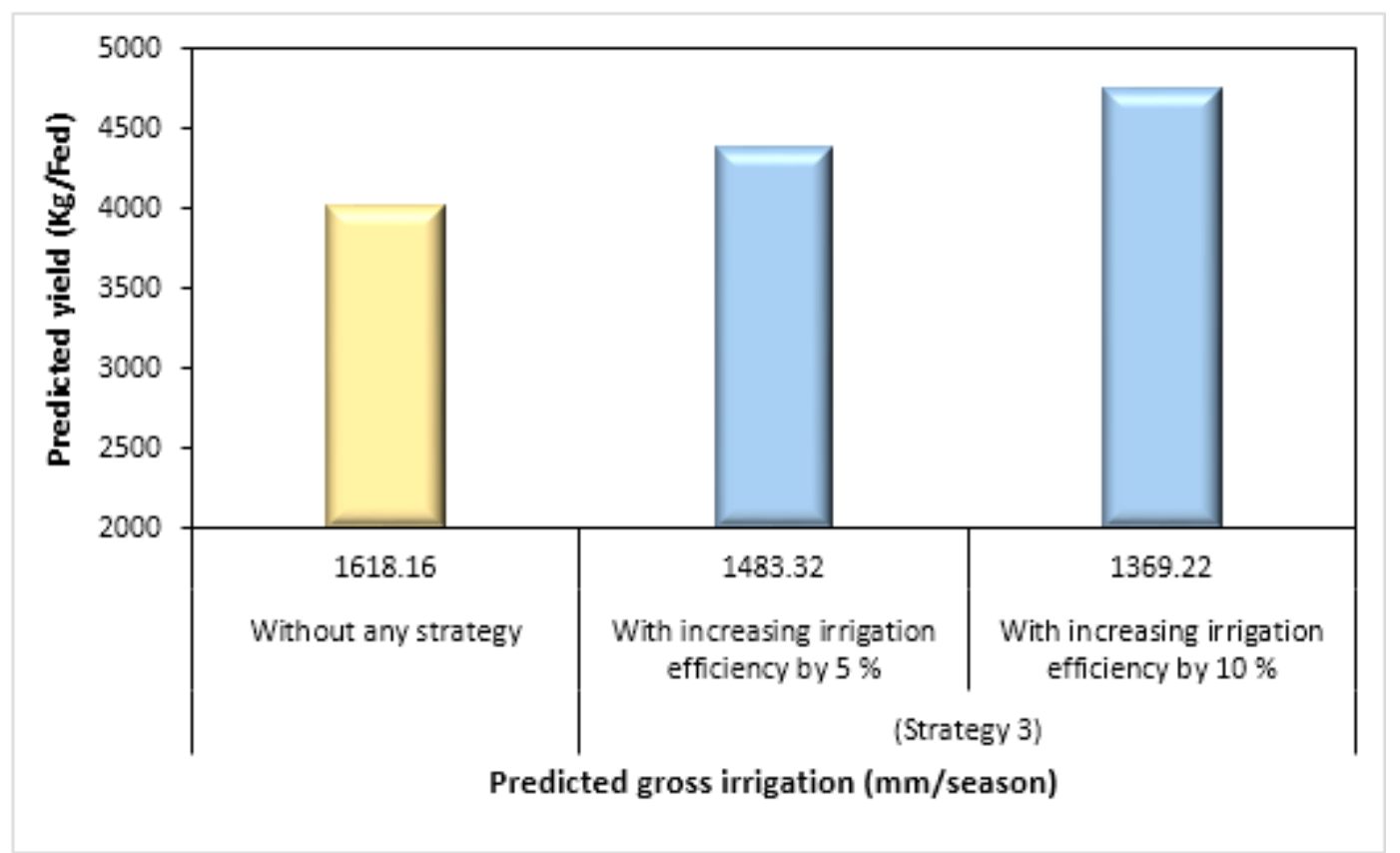

Fig. (10): Relationship between the predicted changes in yield and gross irrigation for corn crop in EI-Dakahlia governorate during 2040s under strategy3.

\section{CONCLUSION}

Irrigation water management was, predicted using CAPIM model, for corn crop at different geographic regions in Egypt under the RCP8.5 scenario and MIROC-ESM climate models during the years of 2018s, 2040s and 2080s. The CAPIM model results showed a high reliability in calculating reference evapotranspiration with the highest degree of confidence under different irrigation application situations. Moreover, the results for scheduling and developing strategies were satisfactory.

The CAPIM model revealed that the GIR in El- Fayoum Governorate increased by $28 \%$ in 2080s and $29 \%$ in 2040s with totaling of 2008 and $2077 \mathrm{~mm} /$ season, respectively.

Based on the results of the three strategies, the third strategy of increasing irrigation system efficiency by $5 \%$ or $10 \%$ was projected to be better than first and second strategies. While the GIR was expected to decrease and reaches 1483 and $1369 \mathrm{~mm} /$ season under 5\% and 10\%, respectively. The predicted potential yield increased by about $9 \%$ and $18 \%$ and the WP by $9.4 \%$ and $18.7 \%$, respectively.

Further studies on predicting the impact of the climatic changes on the irrigation water management on the field level using different climate scenarios and models will allow accounting for uncertainties related to future emissions trajectory and its impact on the predicted irrigation management. More applications of the CAPIM model are needed for major crops in different agricultural areas in Egypt before submitting the model to extended works.

\section{REFERENCES}

Abdel Meguid, M. (2017) Key features of the Egypt's water and agricultural resources. In: Negm, A.M. (Ed.), Conventional Water Resources and Agriculture in Egypt. Springer Berlin Heidelberg, Berlin, Heidelberg, pp. 1-61. 
Abdel-Hafez, S. A. (2011) Opportunities and Challenges in the old lands of Egypt. Background paper for Egypt, Australlia, ICARDA. Workshop on-on Farm Water use Efficiencyll, 26-29 July, 2011, Cairo, Egypt.

Abouelenein, R, T. Oweis, M. El Sherif, H. Awad, F. Foaad, S. Abd El Hafez, A. Hammam, F. Karajeh, M. Karo and A. Linda (2009) Improving wheat water productivity under different methods of irrigation management and nitrogen fertilizer rates. Egypt J Appl Sci 24(12A):417-431.

Ali, M.H., Talukder, M.S.U. (2008) Increasing water productivity in crop production. A synthesis. Agric. Water Manage. 95, 1201-1213.

Allen, R. G., M. E. Jensen, J. L. Wright and R. D. Burman 1989. Operational estimate of reference evapotranspiration. Agron J 81: 650-662. http: // dx.doi.org / 10. 2134 / agron. j. 1989.

Arnell, N. W., D. P. van Vuuren and M. Isaac (2011) The implications of climate policy forthe impacts of climate change on global water resources. Glob. Environ. Change 21, $592-603$.

BAS (2014) Bulletin of the Agricultural Statistics. Republic of Namibia Ministry of Agriculture, Water and Forestry April.

FAO (1979) Yield response to water by J. Doorenbos \& A. Kassam. FAO Irrigation and Drainage Paper No. 33. Rome.

FAO (1998) Crop evapotranspiration: Guidelines for computing crop water requirements. By: Richard Allen, Luis Pereira, Dirk Raes and Martin Smith. FAO Irrigation and Drainage Paper 56. Rome, Italy.

FAO (2017) AquaCrop update and new features Version 6.0. ISBN 978-92-5-109742-7 (C) FAO, 2017.

France, J. and J. Thornely (1984) Mathematical models in Agriculture. Butter worth's, London, UK, 335P.

Hagemann, S S. Hagemann, C. Chen, D. B. Clark, S. Folwell, S. N. Gosling, I. Haddeland, N. Hanasaki, J. Heinke, F. Ludwig, F. Voß, and A. J. Wiltshire (2012) Climate change impact on available water resources obtained using multiple global climate and hydrology models. Earth Syst Dynam Discuss 3 (3-4):1321-1345.

IPCC (2001) Climate Change 2001: The Scientific Basis. Contribution of Working GroupI to the Third Assessment Report of the Intergovernmental Panel on Climate Change. Houghton, J.T., Ding, Y., Griggs, D.J., Noguer, M., van der Linden, P.J., Dai, X., Maskell, K. and Johnson, C.A. (Eds.). Cambridge University Press, Cambridge, United Kingdom and New York, NY, USA, 881pp.

Irmak, A. and S. Irmak (2008) Reference and crop evapotranspiration in south central Nebraska: II. Measurement and estimation of actual evapotranspiration. Journal of Irrigation and Drainage Engineering, 134(6), 700-715. https://doi.Org/10.1061/ (ASCE) 0733-9437 (2008) 134:6 (700). 
Milan,G. and S. Trajkovic (2010) Software for estimating reference evapotranspiration using limited weather data. Computers and Electronics in Agriculture 71 (2010) 158162 doi:10.1016/j.compag.2010.01.003

Mahmoud, M. M. A. and A. Z. El-Bably (2017) Crop Water Requirements and Irrigation Efficiencies in Egypt. DOI: 10.1007/698 -2017- 42.

SAVVA, A. P. and K. FRENKEN 2002. Crop Water Requirements and Irrigation Scheduling Water Resources Development and Management Officers FAO SubRegional Office for East and Southern Africa.

Shahidian, S., R. Serralheiro, J. Serrano, J. Teixeira, N. Haie and S. Francisco (2012) Hargreaves and other reduced-set methods for calculating evapotranspiration. In: Evapotranspiration - Remote sensing and modeling (Irmak A, ed.), InTech.Available in http://www.intechopen.com/books/evapotranspiration remote sensing and modeling/Hargreaves and other reduced set methods for calculating evapotranspiration.

Smith, M., G. V. Halsema, F. Maraux, G. Izzi, R. Wahaj and G. Munoz (2007) CropWat 8, Windows Version 8.0. Water resources development and management service, FAO, Rome, Italy.

Thornton, P. K., P. G. Jones, P. J. Ericksen and A. J. Challinor (2011) Agriculture and food systems in sub-Saharan Africa in a $4 \mathrm{C}+$ world.mPhilos. Trans. R. Soc. A: Math. Phys. Eng. Sci. 369 (1934), 117-136.

Wang, X. J., J. Y. Zhang, M. Ali, S. Shahid, R. M. He, X. H. Xia and Z. Jiang (2016) Impact of climate change on regional irrigation water demand in Baojixia irrigation district of China. Mitig. Adapt. Strateg. Glob. Chang. 2016, 21, 233-247. [CrossRef]. 


\section{نموذج للتنبؤ وتحسين إدارة المياه في مصر - محصول الذرة كدراسة حالة

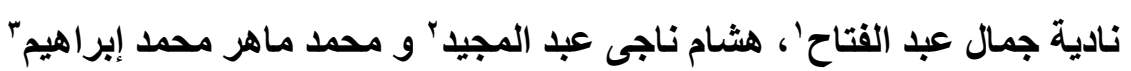

' مدرس بقسم الهندسة الزر اعبة ـ كلية الزر اعة - جامعة المنصورة ـ مصر.

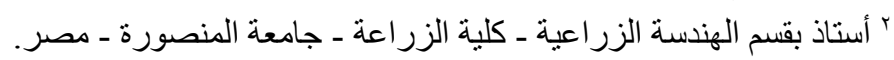

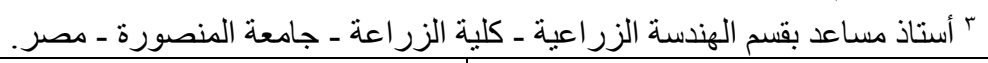

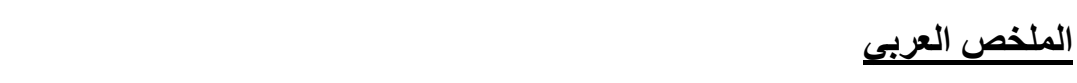

استنبط نموذج لإدارة مياه الري تحت الظروف المناخية الحالية و المتوقعة قصيرة

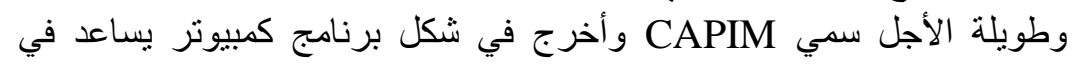

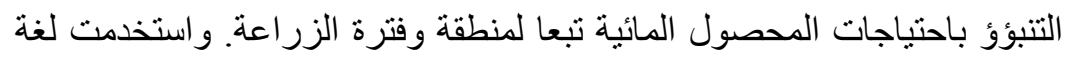
البرمجة Oracle.

تم تطبيق النموذج لجدولة مياه الري لمحصول الذرة في محافظات الدقهلية و الفيوم

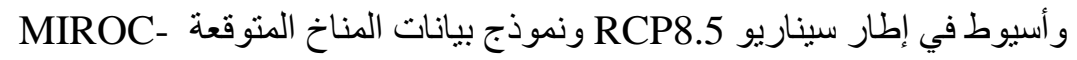

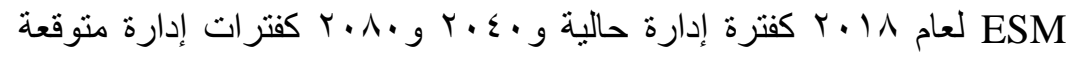

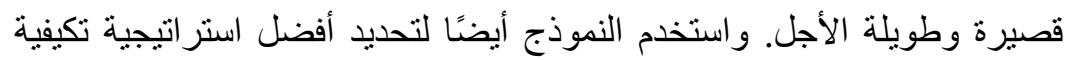

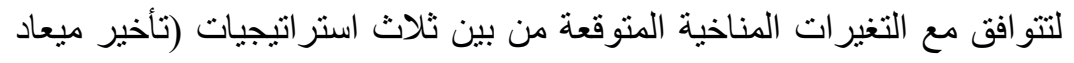

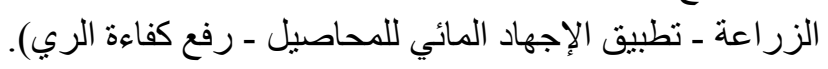

وتم التحقق من دقة مخرجات النموذج لقيم

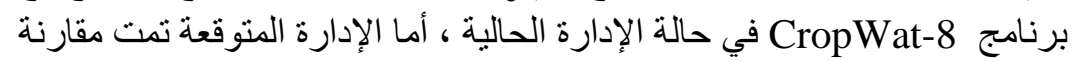

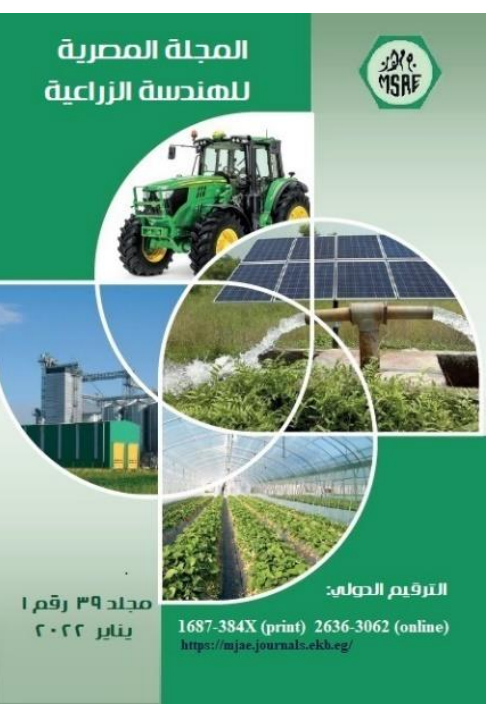
النتائج بيرنامج Estimation

(المجلة المصرية للهنسة الزراعية

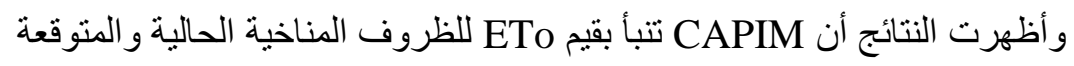

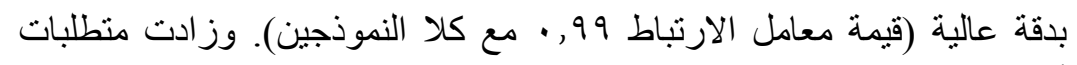

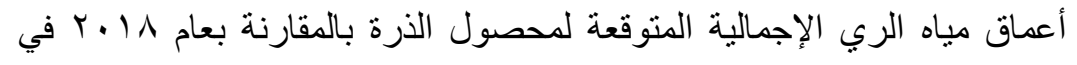

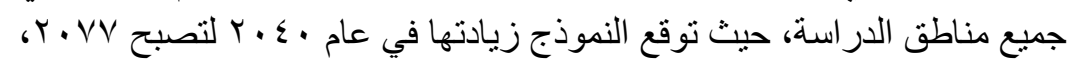

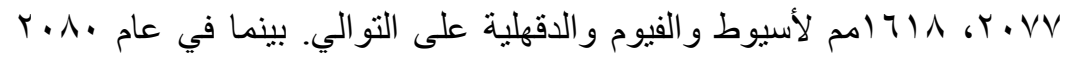

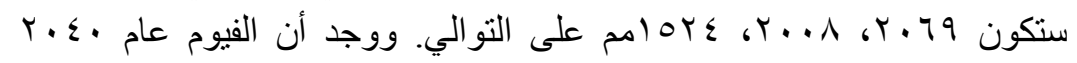

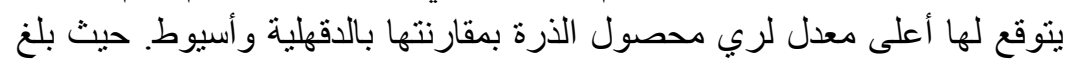

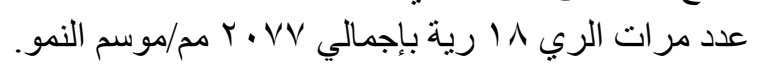

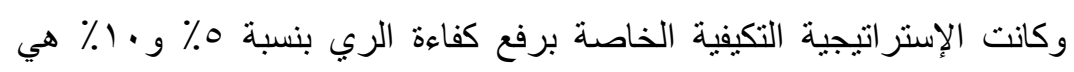

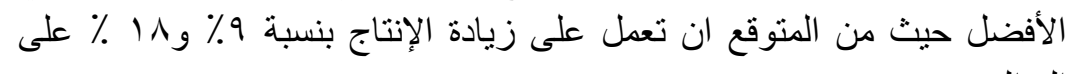

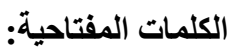

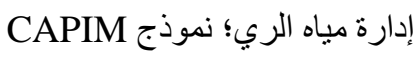

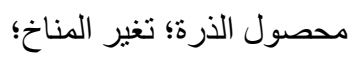
سيناريو هات المناخ. التوالي. 